\title{
Winter Roosting by Eastern Red Bats in Ozark Mountain Forests of Missouri
}

\author{
Joshua R. Flinn ${ }^{1,2}$, Roger W. Perry ${ }^{3, * \mathbb{D}}$ and Lynn W. Robbins ${ }^{1,4}$ \\ 1 Department of Biology, Missouri State University, 901 S. National Avenue, Springfield, MO 65897, USA; \\ Josh.Flinn@stantec.com (J.R.F.); lrobbins@envsi.com (L.W.R.) \\ 2 Stantec Consulting Services, Inc., 6800 College Boulevard, Suite 750, Overland Park, KS 66211, USA \\ 3 U.S. Forest Service, Southern Research Station, P.O. Box 1270, Hot Springs, AR 71902, USA \\ 4 Environmental Solutions and Innovations, 3851 S. Jefferson Avenue, Springfield, MO 65807, USA \\ * Correspondence: roger.perry@usda.gov; Tel.: +1-501-623-1180 (ext. 108)
}

Citation: Flinn, J.R.; Perry, R.W.; Robbins, L.W. Winter Roosting by Eastern Red Bats in Ozark Mountain Forests of Missouri. Forests 2021, 12, 1769. https://doi.org/10.3390/ f12121769

Academic Editor: Todd Fredericksen

Received: 28 October 2021

Accepted: 10 December 2021

Published: 14 December 2021

Publisher's Note: MDPI stays neutral with regard to jurisdictional claims in published maps and institutional affiliations.

Copyright: (c) 2021 by the authors. Licensee MDPI, Basel, Switzerland. This article is an open access article distributed under the terms and conditions of the Creative Commons Attribution (CC BY) license (https:// creativecommons.org/licenses/by/ $4.0 /)$.

\begin{abstract}
The eastern red bat (Lasiurus borealis Müller, 1776) is a widespread species that roosts in evergreen or dead foliage suspended in trees during winter but retreats to leaf litter during colder periods. Roosting in leaf litter by eastern red bats makes them vulnerable to prescribed fires in winter. Using radio telemetry, we tracked 33 male eastern red bats to 101 winter (November-February) roosts and quantified roost locations, habitat surrounding roosts, and landscape attributes of roost locations. When roosting in trees, bats preferred oaks but generally avoided other tree species; they used pines in proportion to their availability. During colder periods, bats retreated to roosts in leaf litter where $21 \%$ suffered mortality either from predation/scavenging or unknown causes while roosting on the ground. Models of roost selection indicated that southerly aspect was the most important factor determining roost selection, and both tree- and leaf-litter roosts were predominately $(\geq 94 \%)$ on upper south-facing slopes. Prescribed burning in late morning/early afternoon on clear days when temperatures under leaf litter are warmest in winter could reduce potential mortality by allowing faster arousal time for hibernating bats.
\end{abstract}

Keywords: aspect; bats; burning; eastern red bat; leaf litter; prescribed fire; winter roosting

\section{Introduction}

The eastern red bat (Lasiurus borealis Müller, 1776) is a geographically widespread, foliage-roosting species that inhabits forested areas in North America east of the Rocky Mountains [1]. During summer, it ranges from Canada to Mexico, inhabiting both deciduous and coniferous forests [1]. The winter range is not well defined, but anecdotal evidence indicates low or no captures in northern latitudes during winter, suggesting they migrate to warmer latitudes [2]. Winter observations of red bats are known as far north as Missouri [3,4], Illinois and Indiana [5], Kentucky [6], and West Virginia [7], where they are often observed flying and foraging on warm evenings before dusk, even when overnight temperatures are below freezing $[4,5,8]$.

Although historical and current population numbers of red bats are unknown, their numbers may be declining [9]. Eastern red bats are migratory [2] and wind power development may pose a threat to populations $[10,11]$. Furthermore, the roosting behavior of eastern red bats during winter makes them susceptible to disturbance from forestmanagement practices, primarily prescribed burning $[4,12,13]$.

Eastern red bats roost in the foliage of numerous tree species above ground and under leaf litter during winter $[3,4,14,15]$ and this roosting behavior is thermally dependent. During winter, lasiurine bats may select southern aspects for roosting that provide solar exposure; they may retreat to roosts below leaf litter during colder periods of winter $[4,12]$. Most temperate bats undergo torpor to reduce energy use when they are inactive, and lower ambient air temperatures correspond with longer arousal times [16]. When temperatures 
approach freezing, red bats and the related Seminole bat (Lasiurus seminolus Rhoads, 1895) abandon tree roots in favor of leaf litter, which provides a warmer and more stable microclimate for energy conservation $[4,12]$. However, eastern red bats roosting in leaf litter may take up to $30 \mathrm{~min}$ to arouse [16]. This ground-roosting behavior of eastern red bats may make them vulnerable to prescribed fires and red bats are often observed exiting leaf litter and fleeing from approaching fires during winter prescribed burns $[7,14,15]$.

Silvicultural treatments such as prescribed burning are implemented on forests throughout the U.S. for various reasons, including to reduce potential catastrophic wildfires, improve wildlife habitat, and to improve forest productivity. Burning is also used for restoring historic forest conditions that existed prior to wide-spread fire-suppression activities in the U.S. during the 1900s e.g., [17]. Although effects of prescribed burning on bats have been summarized by various authors [13,17-21], including the effects of previous fires on the activity of bats during winter [22], information on winter habitat requirements of eastern red bats is needed by land managers to mitigate these forestry practices so they are compatible with overwintering bat communities. The goal of this study was to characterize winter roost selection in mixed deciduous/coniferous forests to determine how tree characteristics, forest structure, and landscape elements affected winter roost selection. This information can be used to aid conservation planning and mitigation for this wide-ranging species.

\section{Materials and Methods}

\subsection{Study Area}

Field work was conducted at Peck Ranch Conservation Area (PRCA) in Shannon and Carter counties of Missouri, located in the Mark Twain National Forest. Terrain was typical of the Ozark region, which was primarily hilly karst topography. Several drainages including Roger's Creek and Mill Creek ran through the study area. Elevation ranged from $178 \mathrm{~m}$ to $408 \mathrm{~m}$ above sea level. For a more detailed description, including maps of the study area, see [23].

The area was owned by the Missouri Department of Conservation and the management focus was primarily glade restoration and pine forest regeneration. PRCA was mostly forest with glades, old fields, savannas, crop lands, and wetlands. Forested areas were diverse in structure and species composition ranged from early succession to mature stands composed of shortleaf pines (Pinus echinate Mill.), oaks (Quercus spp.), hickories (Carya spp.), maples (Acer spp.) and a variety of understory tree species, including redbud (Cercis canadensis L.) dogwood (Cornus florida L.), and serviceberry (Amelanchier arborea F. Michx. Fernald). Gravel or dirt logging and service roads existed throughout the forested areas and provided vehicle access to forest interiors and served as boundaries for management units. Since 1989, approximately one-third of the area was managed with prescribed fire. Average monthly temperature in winter (December-February) for this region were $1.5^{\circ} \mathrm{C}$ and precipitation averages $8.79 \mathrm{~cm}$ (Missouri Climate Center; http:/ / climate.missouri.edu/modata.php (accessed on 28 May 2007)). Winds were predominately from the northwest during the winter months.

\subsection{Capture and Radio-Tracking}

We netted bats during 65 nights from September through March of 2005-2006 and 2006-2007. However, we radio tracked bats to their roosts only during the winter months (late November to late February; winter, hereafter) after leaf off. We captured eastern red bats in single or double-stacked 4-tiered nylon mist nets (Avinet, Dryden, NY, USA) of various lengths $(6,9$, and $12 \mathrm{~m})$ and heights $(2.4$ and $4 \mathrm{~m})$ set across dirt and gravel roads on the study area. Netting sites were bordered by forest on both sides of the road. Because leaves are generally sparse on trees during the winter months, a false canopy was constructed above netting locations with plastic mesh, which increased capture success by forcing bats to fly lower and into the net. 
For captured bats, we determined sex and mass (g); age was not determined because of the inaccuracy of aging bats based on ossification of the finger bones in winter [24]. We attached radio transmitters (0.51 g, LB-2, Holohil Systems Ltd., Carp, Ottawa, ON, Canada) to bats dorsally between the scapulae with surgical adhesive (Skin Bond, Smith and Nephew Inc., Largo, FL, USA). Transmitter mass averaged 5.1\% of bat mass (range 3.9-6.3). We used an R-1000 radio receiver (Communication Specialists, Orange, CA, USA) connected to a three-element Yagi antenna (AF Antronics Inc., Urbana, IL, USA) to track bats, which were released at the point of capture. The time from capture to release was usually $<1 \mathrm{~h}$. We captured only male bats during the winter months (November-February), thus only males were included in our analyses.

We tracked bats the morning after release and continued recording roosting locations on successive days until the transmitter failed, fatality occurred, or the bat flew out of receiving range. A helicopter outfitted with telemetry equipment was used on three occasions to search for missing bats. When diurnal roosts were discovered, we used GPS (Garmin, Olathe, KS, USA) to record the coordinates (5 m accuracy). Roosts were classified as either tree (bat hanging from the branches or foliage of a tree) or leaf-litter (bat on or under the leaf litter of the forest floor). Residence time was calculated by determining the number of successive days a bat remained at a particular roost [25].

\subsection{Roost-Site Characterization}

To determine if attributes of roosts differed from random, we generated a set of random points to compare with roost locations. We constructed a minimum convex polygon (MCP) around all bat roost locations within the study area to determine the area of available habitat. We then generated random points within this MCP using Hawth's Analysis Tools extension for GIS [26]. Habitat variables measured at these random locations were compared to variables measured at roost locations to determine use versus available habitat.

For both tree and litter roosts, we characterized habitat attributes only after the bats had left the roosts to avoid disturbing roosting bats. We recorded the following attributes for tree roosts: tree species, height $(\mathrm{m})$ with a clinometer, diameter at breast height ( $\mathrm{dbh} ; \mathrm{cm})$; height to bat from the ground $(\mathrm{m})$ with a clinometer, and aspect (degrees) of the bat relative to the tree trunk. A $12-\mathrm{m}$ radius plot (0.045 ha) around the roost tree (site, hereafter) was marked to characterize stand-level habitat. We measured and tallied the dbh of all trees $\geq 5 \mathrm{~cm}$ dbh within each site plot. Trees were classified as coniferous or deciduous, and live or snag (dead tree). From these measurements, we determined density (trees/ha) of deciduous trees, coniferous trees, snags, and total trees. We collected canopy cover scores below roost trees based on the method of Mormann and Robbins [4] but did not compare canopy cover scores of roost trees to random trees.

For leaf-litter roosts, we characterized attributes following the methods of Mormann and Robbins [4]. We flagged a $10 \mathrm{~m} \times 10 \mathrm{~m}$ area (site), centered on the roost and recorded $\mathrm{dbh}$ of all trees $\geq 5 \mathrm{~cm}$ dbh, classified as deciduous or coniferous and live or snag. We centered a $50 \times 50 \mathrm{~cm}$ square plot on the litter roost location. Partitioning the site into plots allowed for microhabitat variables to be measured, including litter depth, stem density (number of trees $<5 \mathrm{~cm} \mathrm{dbh}$ ), and percent leaf cover. We selected five additional plots surrounding litter roosts within the same $10 \mathrm{~m} \times 10 \mathrm{~m}$ site, using a random azimuths and distances generated with a random numbers table [27]. Within each of the six plots (1 roost plot, 5 additional plots), leaf litter depth was measured at the center and $10 \mathrm{~cm}$ from the center in all four cardinal directions; liter depth was averaged for each plot. We counted all woody stems (trees $<5 \mathrm{~cm}$ dbh) in each plot and visually estimated the percentage of ground covered by leaf litter. Each variable from the six plots was averaged to obtain one value for the site. We recorded aspect of litter roosts based on the aspect of the slope at the site where the bat was located.

For both tree roosts and litter roosts, we recorded elevation, slope, and distance to nearest road. We classified the study area into 9 land use/land cover (LULC) classes based on forest type and previous management; we determined the percentage of the landscape 
composed by each cover class using ArcGIS (ESRI, Redlands, CA). We summarized burn history effects on roosting by determining whether stands (used and unused) were burned in the past 3 years and compared the frequency of roosts in recently burned stands to unburned stands.

\subsection{Analyses}

We used logistic regression to create separate models for tree roosts and litter roosts that related landscape and habitat parameters with an increased likelihood of bat roosting. We removed highly correlated $(\mathrm{r} \geq 0.70)$ variables prior to analysis. We transformed aspect (a circular variable) into 6 classes, with northern aspects $\left(330-30^{\circ}\right)=0$ and southern aspects $\left(150-210^{\circ}\right)=5$; eastern and western aspects were separated by $30^{\circ}$ increments representing Classes 1-4. For tree-roosts, we compared 27 candidate models that included various combinations of both landscape and plot-level variables (elevation, slope, aspect, canopy cover, stem density, litter depth) based on our best predictions of potentially important variables that would affect selection of tree roosts during winter. Likewise, for litter roosts, we compared 30 candidate models to determine the best model or models that described roost selection in leaf litter during winter. We then determined the most parsimonious model among all candidate models (for tree roosts and litter roosts separately) based on the value of Akaike's information criterion (AIC) modified for small samples (AICc) [28]. We used multimodel inference by averaging parameter estimates for models within 2 units of AICmin [28]; we used weights ( $\omega$ i) calculated among all models within 2 units of AICmin for averaging and we calculated odds ratios (odds roost/odds random) from averaged parameters. We computed unconditional SEs for each parameter when multiple models were in the best model set [28].

We compared aspect of roost sites (tree roosts and litter roosts) and orientation of bats in trees (in relation to the tree trunk) with random aspects using Rayleigh's test [27]. We compared characteristics of roosts trees to random trees using Student's t-tests and we compared the number of roosts in each tree LULC class with the available proportions using binomial tests with a z-approximation [27]. We compared canopy cover scores around trees to determine if densities of persistent leaves differed at various aspects. We compared three classes of canopy scores: north $\left(315^{\circ}-45^{\circ}\right)$, south $\left(135^{\circ}-225^{\circ}\right)$, and east/west $\left(45^{\circ}-135^{\circ}\right.$ and $255^{\circ}-315^{\circ}$ ). Canopy scores were compared among these three directions using analysis of variance, with a Tukey's test for mean separation.

\section{Results}

We captured 224 eastern red bats during 156 net nights, with 217 of those bats processed. We captured 211 males but only 6 females, and females were only captured on 9 September $2005(n=5)$ and 10 March $2006(n=1)$. Mean mass of male red bats varied by month, with mass being greatest in November (10.6 g) and least in February (9.4 g), but these differences were non-significant $(\mathrm{F}=1.83, p=0.084)$.

We attached radio transmitters to 45 bats, of which 33 were tracked to at least one roost $(73 \%)$. Seven of these 33 tracked bats $(21 \%)$ suffered mortality from predation/scavenging $(n=4)$ or unknown causes $(n=3)$ while roosting on the ground. Bats were tracked to 101 roost locations (mean $=3.1$ roosts $/$ bat). Of these, 52 were roosts in trees and 49 were in leaf litter. Mean depth of leaf litter at litter roosts was $62.5 \mathrm{~mm} \pm 2.3 \mathrm{SE}$, which was greater than random $(50.7 \pm 3.0 ; \mathrm{t}=3.16, p=0.002)$, and stem density $(<5 \mathrm{~cm} \mathrm{dbh})$ was less at litter roosts $(1.1 \pm 0.1)$ than random plots $(1.7 \pm 0.2 ; \mathrm{t}=2.46, p=0.016)$. Trees roosts were typically in persistent dead leaves, primarily of oaks. Residence time was longer $(\mathrm{t}=4.07, p=<0.001)$ at leaf-litter roosts $(6.7 \pm 1.3$ days; range $=1-40)$ than at tree roosts $(1.5 \pm 0.1$ days; range $=1-4)$. Percentage of bats roosting in leaf litter was negatively correlated with maximum temperature the day of observation $(\mathrm{r}=-0.818, p=0.002)$. Eighteen of the thirty-three tracked bats (54.5\%) utilized both tree and leaf litter roosts during radiotracking. Mean height of the bat in roost trees was $4.01 \mathrm{~m}(n=51$, range $=0.85-14.40 \mathrm{~m})$. Three bats returned to trees previously used as roosts. On one occasion, two bats (one with 
a transmitter and one without) were observed roosting within $1 \mathrm{~m}$ of each other in the same roost tree. Another tree was used by two different bats on separate occasions.

We located 43 separate roost trees, most of which (91\%) were oaks (Table 1). Three roosts were in shortleaf pine, one was in a bitternut hickory (Carya cordiformis Wangenh.; K. Koch), and 39 were in other oak species including Q. stellata, Q. alba, Q. rubra. Oaks were used more than expected based on the proportion of available tree species, whereas hickories and other species combined were used less than expected (Table 1). Pines were used in proportions similar to their availability on the landscape. Both height $(9.1 \pm 0.9 \mathrm{~m})$ and diameter $(13.7 \pm 1.7 \mathrm{~cm}$ dbh) of roost trees were significantly smaller than random trees $($ random tree height $=13.1 \pm 0.9 \mathrm{~m}[\mathrm{t}=3.16, p=0.002]$, diameter $=19.1 \pm 1.9 \mathrm{~cm}$ $\mathrm{dbh}[\mathrm{t}=2.14, p=0.035)$. Six roost trees were $<3 \mathrm{~cm}$ dbh. Most bat roosts $(93 \%)$ were on the south side of tree canopies in relation to the trunk and aspect was not randomly distributed (Rayleigh's test; $z=17.85, p<0.001$; Figure 1A). However, south sides of roost tree canopies had significantly lower canopy cover scores (retained leaves) compared to north or east/west aspects $(\mathrm{F}=6.42, p=0.002)$.

Table 1. Species of trees available (\%) and species used (\%) for 43 tree roosts of eastern red bats during winter in the Missouri Ozarks, 2005-2007; proportions were compared using binomial tests and a z-approximation. Tree classes marked with * were grouped into the "other species" class for analysis.

\begin{tabular}{|c|c|c|c|c|}
\hline Tree Species Group & Available & Roosts & $\mathrm{z}$ & $p$ \\
\hline Oak (Quercus spp.) & 34 & 91 & 6.47 & $<0.001$ \\
\hline Hickory (Carya spp.) & 17 & 2 & -3.11 & 0.002 \\
\hline Shortleaf pine (Pinus echinate Mill.) & 10 & 7 & -1.01 & 0.311 \\
\hline Other species & 19 & 0 & -2.12 & 0.016 \\
\hline Elm (Ulmus spp.) * & 8 & 0 & & \\
\hline Eastern redcedar (Juniperus virginiana L.) * & 2 & 0 & & \\
\hline Flowering dogwood (Cornus florida L.)* & 8 & 0 & & \\
\hline Eastern redbud (Cercis canadensis L.)* & 2 & 0 & & \\
\hline
\end{tabular}

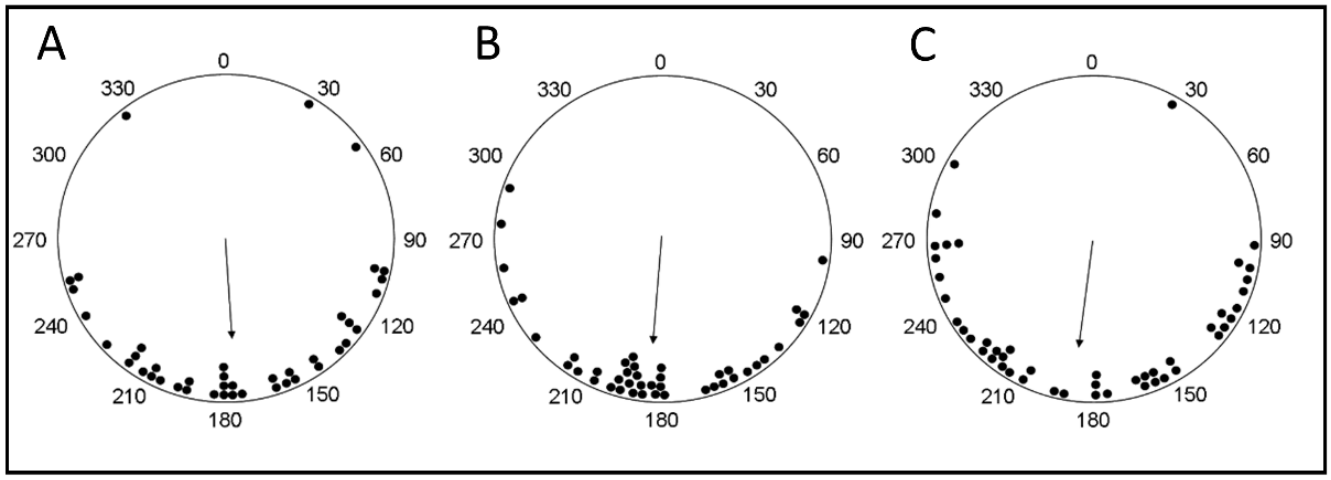

Figure 1. Rayleigh's tests relating aspect of eastern red bat roosts in roost trees, litter roosts, and sites in the Missouri Ozarks, winter 2005-2007. Each dot represents one roost site and arrow indicates mean compass direction of roosts. (A) Aspect of bat location relative to tree trunks when roosting in trees $(\mathrm{z}=17.9, p<0.001, n=42)$; (B) site aspect of trees roosts on the landscape. $(\mathrm{z}=26.8, p<0.001$, $n=43)$; and (C) site aspect of leaf-litter roosts on the landscape. $(\mathrm{z}=15.9, p<0.001, n=47)$.

We quantified habitat characteristics at 43 tree roost sites and 50 random sites. The top model comparing roost sites in trees to random sites contained slope, aspect, elevation, and density of snags/ha (Table 2). Two additional models were within two units AICc from the best model. Averaged parameters from these three models indicated a positive relationship with slope, aspect, elevation, and deciduous trees/ha, and a negative relationship with number of snags/ha and distance to roads (Table 3). However, number of deciduous 
trees / ha and distance to roads were not significant in the models ( $95 \%$ confidence interval for the parameter estimates included zero). Our averaged model indicated bats were 2.77 times more likely to roost in trees on southerly aspects, and most roost trees (95\%) were located on south-facing slopes (Rayleigh's test; $z=26.75, p<0.001$; Figure 1B). Bats were also 1.17 times more likely to roost at sites with greater slope, and 1.13 times more likely to roost at sites at higher elevation. Bats were also slightly less likely to roost at sites with greater snag densities.

Table 2. Top 5 models among 27 candidates for tree roosts and top 5 models among 30 candidate models for litter roosts in which AICc valves were evaluated, including values of AICc and $\triangle \mathrm{AICc}$ (the difference in AICc between a model and the model with the lowest AICc) for modeling roost selection of eastern red bats in the Missouri Ozarks, winter 2005-2007.

\begin{tabular}{ccc}
\hline Variables & AICc & $\Delta$ AICc \\
\hline Tree roosts & & 0 \\
Slope, Aspect, Elevation, Snags/ha & 57.153 & 1.22 \\
Slope, Aspect, Elevation, Snags/ha, RoadDis & 58.375 & 1.48 \\
Slope, Aspect, Elevation, Snags/ha, Decid/ha & 58.637 & 2.22 \\
Slope, Aspect, Elevation, Snags/ha, Decid/ha, & 59.371 & 5.32 \\
$\quad$ Conifer/ha, RoadDist & 62.472 & 0 \\
Slope, Aspect, Elevation & & 2.19 \\
$\quad$ Litter roosts & 91.041 & 3.38 \\
Slope, Aspect, Litter Depth, Litter Cover & 93.231 & 3.94 \\
Slope, Aspect, Litter Depth, Litter Cover, Stem & & \\
Density & 94.418 & 5.58 \\
Slope, Aspect, Litter Depth, Litter Cover, Stem & 94.976 & \\
Density, Elevation & 96.625 &
\end{tabular}

Table 3. Parameter estimates, standard errors of the estimate (SE), $95 \%$ lower confidence limit for the estimate (LCL), 95\% upper confidence limit for the parameter estimate (UCL), and odds ratios for parameters included in models of landscape/habitat parameters associated with tree roosts and litter roosts of eastern red bats during winter in the Missouri Ozarks, 2005-2007. Significant effects (95\% confidence interval for the parameter estimate did not include zero) are designated with *.

\begin{tabular}{cccccc}
\hline Variable & Estimate & SE & LCL & UCL & Odds \\
\hline Tree roosts & & & & & \\
Slope & $* 0.154$ & 0.077 & 0.004 & 0.305 & 1.167 \\
Southerly aspect & $* 1.019$ & 0.276 & 0.477 & 1.561 & 2.770 \\
Elevation & $* 0.118$ & 0.033 & 0.053 & 0.182 & 1.125 \\
Snags/ha & $*-0.223$ & 0.010 & -0.042 & -0.003 & 0.977 \\
Deciduous trees/ha & 0.002 & 0.002 & -0.001 & 0.006 & 1.002 \\
Distance to roads & -0.001 & 0.001 & -0.002 & 0.001 & 0.999 \\
Litter roosts & $* 0.140$ & 0.054 & 0.035 & 0.245 & 1.156 \\
$\quad$ Slope & $* 1.146$ & 0.245 & 0.665 & 1.626 & 3.145 \\
Southerly aspect & -0.018 & 0.024 & -0.066 & 0.030 & 0.982 \\
Litter depth & $* 0.089$ & 0.034 & 0.023 & 0.155 & 1.093 \\
Litter cover & & & & &
\end{tabular}

Our top model comparing litter roost sites to random sites contained slope, aspect, litter cover, and litter depth (Table 2). No other models were within two units AIC of the top model. A positive relationship existed between sites selected for litter roosting and slope, southerly aspects, and percent litter cover, whereas a negative relationship existed for litter depth (Table 3). However, litter depth was not significant in the model (95\% confidence interval for the parameter estimates included zero). This model indicated that litter roosts were more than three times more likely to be found on slopes with southerly aspects, and 
most litter roosts were on slopes with southern aspects (Rayleigh's test; $z=15.9, p<0.001$, $n=47$; Figure 1C). Litter roosts were also 1.1 times more likely to be on steeper slopes than random and percent cover of leaf litter at litter roost sites was slightly greater than at random sites.

Red bats roosted in three of nine LULC land classes: upland deciduous forest, shortleaf pine-oak mixed forest and woodland, and glade complex (Table 4). Bats roosted more often than expected in upland deciduous forest and less often than expected in pine-dominated forest and other LULC classes. Bats roosted significantly more often in unburned areas than in recently burned areas, with 15 roosts (16\%) located in areas that had been burned within the past 3 years compared with 77 roosts $(84 \%)$ located in unburned management units $\left(\chi^{2}=10.9\right.$, d.f. $\left.=1, p<0.001\right)$; expected frequencies were 30 roosts $(33 \%)$ in burned areas and 62 roosts $(67 \%)$ in unburned areas.

Table 4. Percent available of each land use-land cover (LULC) class and percent of 94 roost sites (tree and litter roosts combined) in each LULC class for eastern red bats during winter in the Missouri Ozarks, 2005-2007. Proportional use and availability were compared using binomial tests and a z-approximation. LULC classes grouped into the "other LULC classes" for analysis are designated with *.

\begin{tabular}{ccccc}
\hline Land Cover Class & Available $\%$ & Used $\%$ & z & $p$ \\
\hline Upland deciduous forest & 65 & 80 & 3.32 & $<0.001$ \\
Mixed shortleaf pine-oak forest and woodland & 28 & 16 & -2.50 & 0.013 \\
Other LULC classes & 6 & 2 & -2.90 & 0.004 \\
Shortleaf pine forest and woodland * & 3 & 0 & & \\
Deciduous woodland * & 1 & 0 & & \\
Glade complex * $_{\text {Cool-season grassland * }}$ & 1 & 2 & \\
\hline
\end{tabular}

\section{Discussion}

Eastern red bats and some other bat species that remain active during winter in temperate regions often retreat to leaf litter or other locations near the ground when temperatures approached freezing $[4,12,29]$. We found eastern red bats roosted in persistent foliage of trees during winter but spent more time roosting beneath leaf litter on the forest floor. Because torpor bout duration is longer at lower temperatures [30], colder air temperatures likely contributed to longer residence times under leaf litter.

Roosts trees were mostly oaks with persistent leaves and in trees smaller than random, likely because these smaller oaks retain leaves more than other species in winter. Marcesence, whereby a typically deciduous species retains leaves throughout winter, is a juvenile trait seen in smaller, young trees or the lower branches of larger trees [31]. During summer, bats generally prefer large diameter trees for roost structures during the maternity period [32], and eastern red bats during summer typically roost in overstory trees that are larger than most trees on the landscape [33-36]. Persistent leaves in winter may offer protection from wind, but also serve as camouflage to protect against predators. Hickories and other species in the study area that did not retain leaves were used less than expected, whereas pines were used in proportion to their availability. In other areas, eastern red bats use eastern redcedar (Juniperus virginiana L.) extensively during winter [4], which also provides protection from wind and provides camouflage protection, but eastern redcedars were uncommon in our study area.

Landscape attributes were far more important than stand-level features for winter roosting by eastern red bats. In particular, southerly aspects had the highest odds ratios in models of habitat selection and bats were nearly three times more likely to roost (both in trees and in leaf litter) on southerly slopes. Aspect of roosts was disproportionately south facing for tree roost sites (95\%), leaf litter roost sites (94\%), and bat positions in tree canopies relative to the trunk (93\%), similar to results found in southwestern Missouri [4]. Southerly aspects reduce the potential for freezing in this northern portion of the red bat's winter 
range and south aspects increase solar exposure to aid passive warming. Further, roosts tended to be at higher elevations than random. Colder air often settles into valleys during clear, windless nights [37], and southerly slopes at higher elevations had significantly warmer temperatures across our study landscape during winter [23].

We found litter cover was a significant factor determining selection of roosts in leaf litter, whereas litter depth was not a significant contributor in our model. Perry [38] found locations below leaf litter were significantly warmer than ambient temperatures, but depth of leaf litter had negligible effects on temperatures below leaf litter. Temperatures beneath leaf litter are warmer on south slopes than on north slopes but estimated energy expenditures of hibernating red bats may not differ among aspects [38]. Heat radiating from the ground is trapped by the leaf litter, which creates a thermal refuge for bats; however, average ground temperatures decline from November to February and the thermal benefits of roosting under leaf litter likely decline as winter progresses [38].

Regardless of bat responses to differences in landscape temperature, $21 \%$ of bats that we tracked died. Eastern red bats exposed to temperatures below $-5{ }^{\circ} \mathrm{C}$ during torpor may freeze to death if they do not increase their metabolism to generate body heat [30]. Thus, it is possible that some or all of these bats froze to death. One bat roosting in a tree was found dead hanging in a tree and coated in ice after an ice storm. We were unsure if bats found dead under leaf litter were scavenged after dying or were alive when depredated, but scavenging was apparent in four of the seven dead bats. All of the bats that showed signs of predation/scavenging were located at or near their roosting site on the ground. White-footed mice (Peromyscus leucopus Rafinesque) were captured near these sites of ground predation/scavenging, and these and other small mammals could potentially have contributed to this mortality $[39,40]$. Consequently, eastern red bats may be subjected to relatively high mortality rates during winter compared to cave-hibernating species, which may be offset by their relatively higher reproductive rates compared to other bat species.

All bats located during our study were males. Reports of female captures are rare in studies aimed at describing winter habitat use by eastern red bats [4]. Similarly, Hein et al. [12] captured no female Seminole bats (a species closely related to eastern red bats) in South Carolina during a winter. We only captured females in mist-nets in mid-September and again in mid-March and two females we instrumented were not located, suggesting these bats were early or late migrants. However, on 26 January, we hand-captured a female red bat that landed in a small tree after being flushed during a prescribed burn, suggesting females are either rare at this latitude during winter or they spend winter hibernating rather than feeding during warmer evenings. Male bats often weigh less than females and have lower flight costs, and it is possible that only males may be active at cooler temperatures [41]. Nevertheless, more information is needed on habitat use and winter roosting behavior of female eastern red bats.

Ambient temperatures are likely important when conducting winter prescribed burning across forested landscapes in the region. Red bats typically roost in trees when temperatures exceed $10^{\circ} \mathrm{C}$ during winter [4] and Seminole bats may roost extensively on or near the forest floor when minimum nightly temperatures fall below $4{ }^{\circ} \mathrm{C}$ [12]. Thus, prescribed burning of forests during the dormant season has the potential to affect roosting bats, especially during cold periods when eastern red bats are likely roosting beneath the leaf litter. We found eastern red bats selected higher elevation sites on steep, southerly slopes; these areas typically burn hotter and faster than other locations across the landscape [42,43]. These upper slopes of southern aspects also support the greatest ambient temperatures during winter across the study area [23]. Because eastern red bats arouse quicker at higher temperatures [16], greater leaf-litter temperatures experienced by bats on south slopes would provide quicker escape times from disturbances such as fire.

Prescribed burns are typically ignited in late morning or early afternoon, when humidity levels are lower [13] and under leaf temperatures are greatest, especially on southern slopes where mid-morning and afternoon sun heats the forest floor [44]. Layne et al. [16] found eastern red bats aroused $>2 \times$ times faster at $5{ }^{\circ} \mathrm{C}$ when exposed to smoke and the 
sound of fire than without these stimuli, suggesting fire provides cues that cause these bats to arouse quickly. Reports of eastern red bats exiting leaf litter during prescribed burns are common e.g., [14,15], suggesting they are often able to arouse and escape approaching flames. We found most $(84 \%)$ roosts in areas that had not been burned in the previous 3 years, suggesting that short-term reductions in leaf litter caused by prescribed burning may temporarily reduce winter habitat for red bats.

\section{Conclusions}

During winter, eastern red bats were plastic in their roosting strategy and roosted primarily in leaf litter on upper south slopes during winter. Consequently, care should be taken when burning these areas during colder periods $\left(<10^{\circ} \mathrm{C}\right)$ of winter. Burning in late morning or early afternoon, especially on clear days, would allow solar heating of leaf litter and subsequent higher temperatures experienced by bats under litter [44]. These higher temperatures would allow for faster arousal from torpor and quicker escape times by eastern red bats during burning.

Author Contributions: Study design, data collection, and initial analyses and writing were carried out by J.R.F. Revised data analysis, interpretation, manuscript preparation, and submission were carried out by R.W.P. Study conceived and supervised by L.W.R. All authors have read and agreed to the published version of the manuscript.

Funding: This research was made possible through the funding and cooperation of Missouri Department of Conservation, Missouri State University, and Dickerson Park Zoo.

Institutional Review Board Statement: Protocols followed guidelines for animal use in research and were approved by the Missouri State University Institutional Animal Care and Use Committee (Protocol 2008U).

Informed Consent Statement: Not applicable.

Data Availability Statement: Not applicable.

Acknowledgments: We thank the following individuals from the Missouri Department of Conservation for logistical and field support: Jeremy Kolaks, Carrie Steen, Kimberly Houf, André Wilberding, Marshall Price, Dan Drees, Mike Norris, John Reed, and John Westenbroek. We also thank Brad Mormann, Justin Boyles, John Timpone, Dillon Jackson, Brandon Carney, Christin Dzurick Byrd, Anna Scesny, Katie Baker, Shelly Colatskie, Victoria Jackson, Tom Tomasi, J.T. Layne, and Lisa Flinn.

Conflicts of Interest: The authors declare no conflict of interest. The use of trade or firm names in this publication is for reader information and does not imply endorsement of any product or service by the USA Department of Agriculture. This research was conducted in part by a U.S. Government employee on official time, and therefore it is in the public domain and not subject to copyright. The findings and conclusions in this publication are those of the authors and should not be construed to represent an official USDA, Forest Service, or U.S. Government determination or policy.

\section{References}

1. Shump, K.A., Jr.; Shump, A.U. Lasiurus borealis. Mamm. Species 1982, 183, 1-6. [CrossRef]

2. Cryan, P.M. Seasonal distribution of migratory tree bats (Lasiurus and Lasionycteris) in North America. J. Mammal. 2003, 84, 579-593. [CrossRef]

3. Boyles, J.G.; Timpone, J.C.; Robbins, L.W. Late-winter observations of red bats, Lasiurus borealis, and evening bats, Nycticeius humeralis, in Missouri. Bat Res. News 2003, 44, 59-61.

4. Mormann, B.M.; Robbins, L.W. Winter roosting ecology of eastern red bats in southwest Missouri. J. Wildl. Manag. 2007, 71, 213-217. [CrossRef]

5. Davis, W.H.; Lidicker, W.Z., Jr. Winter range of the red bat, Lasiurus borealis. J. Mammal. 1956, 37, 280-291. [CrossRef]

6. Koontz, T.; Davis, W. Winter roosting of the red bat, Lasiurus borealis. Bat Res. News 1991, 32, 3-4.

7. Rodrigue, J.L.; Schuler, T.M.; Menzel, M.A. Observations of bat activity during prescribed burning in West Virginia. Bat Res. News 2001, 42, 48-49.

8. Whitaker, J.O., Jr.; Rose, R.K.; Padgett, T.M. Food of the red bat Lasiurus borealis in winter in the Great Dismal Swamp, North Carolina and Virginia. Am. Midl. Nat. 1997, 137, 408-412. 
9. Winhold, L.; Kurta, A.; Foster, R. Long-term change in an assemblage of North American bats: Are eastern red bats declining? Acta Chiropterol. 2008, 10, 359-366. [CrossRef]

10. Kunz, T.H.; Arnett, E.B.; Erickson, W.P.; Hoar, A.R.; Johnson, G.D.; Larkin, R.P.; Strickland, M.D.; Thresher, R.W.; Tuttle, M.D. Ecological impacts of wind energy development on bats: Questions, research needs, and hypotheses. Front. Ecol. Environ. 2007, 5, 315-324. [CrossRef]

11. Arnett, E.B.; Brown, W.K.; Erickson, W.P.; Fiedler, J.K.; Hamilton, B.L.; Henry, T.H.; Jain, A.; Johnson, G.D.; Kerns, J.; Koford, R.R.; et al. Patterns of bat fatalities at wind energy facilities in North America. J. Wildl. Manag. 2008, 72, 61-78. [CrossRef]

12. Hein, C.D.; Castleberry, S.B.; Miller, K.V. Male Seminole bat winter roost-site selection in a managed forest. J. Wildl. Manag. 2008, 72, 1756-1764. [CrossRef]

13. Perry, R.W. A review of fire effects on bats and bat habitat in the eastern oaks region. In Proceedings of the 4th Fire in Eastern Oak Forests Conference, Springfield, MO, USA, 17-19 May 2012; USDA Forest Service General Technical Report NRS-P-102. pp. 170-191.

14. Saugey, D.A.; Heath, D.R.; Heidt, G.A. The bats of the Ouachita Mountains. Proc. Arkansas Acad. Sci. 1989, 43, 71-77.

15. Moorman, C.E.; Russell, K.R.; Menzel, M.A.; Lohr, S.M.; Ellenberger, J.E.; Van Lear, D.H. Bats roosting in deciduous leaf litter. Bat Res. News 1999, 40, 74-75.

16. Layne, J.T.; Green, D.; Scesny, A.; Robbins, L.W. Eastern Red Bat Responses to Fire during Winter Torpor. Forests 2021, $12,1347$. [CrossRef]

17. Van Lear, D.H.; Harlow, R.F. Fire in the eastern United States: Influence on wildlife habitat. In The Role of Fire in Nongame Wildlife Management and Community Restoration: Traditional Uses and New Directions; USDA Forest Service General Technical Report NE-288; USDA: Newton Square, PA, USA, 2002; pp. 2-10.

18. Carter, T.C.; Ford, W.M.; Menzel, M.A. Fire and bats in the southeast and mid-Atlantic: More questions than answers. In The Role of Fire in Nongame Wildlife Management and Community Restoration: Traditional Uses and New Directions; USDA Forest Service General Technical Report NE-288; USDA: Newton Square, PA, USA, 2002; pp. 139-143.

19. Keyser, P.D.; Ford, W.M. Influence of fire on mammals in eastern oak forests. In Fire in Eastern Oak Forests: Delivering Science to Land Managers, Proceedings of a Conference; USDA Forest Service General Technical Report NRS-P-1; USDA: Newton Square, PA, USA, 2006; pp. 180-190.

20. Dickinson, M.B.; Lacki, M.J.; Cox, D.R. Fire and the endangered Indiana bat. In Proceedings of the 3rd Fire in Eastern Oak Forests Conference, Carbondale, IL, USA, 20-22 May 2008; USDA Forest Service General Technical Report NRS-P-46. USDA: Newton Square, PA, USA, 2009; pp. 51-75.

21. Loeb, S.C. Qualitative synthesis of temperate bat responses to silvicultural treatments-where do we go from here? J. Mammal. 2020, 101, 1513-1525. [CrossRef]

22. Jorge, M.H.; Sweeten, S.E.; True, M.C.; Freeze, S.R.; Cherry, M.J.; Garrison, E.P.; Taylor, H.; Gorman, M.K.; Ford, W.M. Fire, land cover, and temperature drivers of bat activity in winter. Fire Ecol. 2021, 17, 19. [CrossRef]

23. Flinn, J.R. Winter Roosting Behavior of Red Bats (Lasiurus borealis): Habitat Use, Microclimate, and Effects of Ambient Temperature on Roost Choice. Master's Thesis, Missouri State University, Springfield, MO, USA, 2009.

24. Anthony, E.L.P. Age determination in bats. In Ecological and Behavioral Methods for the Study of Bats; Kunz, T.H., Ed.; Smithsonian Institution Press: Washington, DC, USA, 1988; pp. 47-58.

25. Vonhof, M.J.; Barclay, R.M.R. Roost-site selection and roosting ecology of forest-dwelling bats in southern British Columbia. Can. J. Zool. 1996, 74, 1797-1805. [CrossRef]

26. Beyer, H.L. Hawth's Analysis Tools for ArcGIS. Available online: http://www.spatialecology.com/htools (accessed on 1 December 2008).

27. Zar, J.H. Biostatistical Analysis, 4th ed.; Prentice-Hall: Upper Saddle River, NJ, USA, 1999.

28. Burnham, K.P.; Anderson, D.R. Model Selection and Multimodel Inference: A Practical Information-Theoretic Approach, 2nd ed.; Springer: New York, NY, USA, 2002.

29. Perry, R.W.; Saugey, D.A.; Crump, B.G. Winter roosting ecology of silver-haired bats in an Arkansas Forest. Southeast. Nat. 2010, 9 , 563-572. [CrossRef]

30. Dunbar, M.B.; Tomasi, T.E. Arousal patterns, metabolic rate, and an energy budget of eastern red bats (Lasiurus borealis) in winter. J. Mammal. 2006, 87, 1096-1102. [CrossRef]

31. Schaffalitzky De Muckadell, M. Environmental factors in development stages of trees. In Tree Growth; Kozlowski, T.T., Ed.; Ronald Press: New York, NY, USA, 1962; pp. 289-297.

32. Kalcounis-Rüppell, M.C.; Psyllakis, J.M.; Brigham, R.M. Tree roost selection by bats: An empirical synthesis using meta-analysis. Wildl. Soc. Bull. 2005, 33, 175-190. [CrossRef]

33. Elmore, L.W.; Miller, D.A.; Vilella, F.J. Selection of diurnal roosts by red bats (Lasiurus borealis) in an intensively managed pine forest in Mississippi. For. Ecol. Manag. 2004, 199, 11-20. [CrossRef]

34. Mager, K.J.; Nelson, T.A. Roost-site selection by Eastern red bats (Lasiurus borealis). Am. Mildl. Nat. 2001, 145, 120-126. [CrossRef]

35. Menzel, M.A.; Carter, T.C.; Ford, W.M.; Chapman, B.R.; Ozier, J. Summer roost tree selection by eastern red, Seminole, and evening bats in the upper Coastal Plain of South Carolina. Proc. Annu. Conf. Southeast. Assoc. Fish Wildl. Agencies 2000, 54, 304-313. 
36. Perry, R.W.; Thill, R.E.; Carter, S.A. Sex-specific roost selection by adult red bats in a diverse forested landscape. For. Ecol. Manag. 2007, 253, 48-55. [CrossRef]

37. Perry, R.W. A review of factors affecting cave climates for hibernating bats in temperate North America. Environ. Rev. 2013, 21, 28-39. [CrossRef]

38. Perry, R.W. Potential energy expenditure by litter-roosting bats associated with temperature profiles under leaf litter during winter. J. Therm. Biol. 2013, 38, 467-473. [CrossRef]

39. Fenton, M.B. Population Studies of Myotis lucifugus (Chiroptera: Vespertilionidae) in Ontario. Life Sci. Contr. R. Ont. Mus. 1970, 77,34 .

40. Haarsma, A.; Kaal, R. Predation of wood mice (Apodemus sylvaticus) on hibernating bats. Popul. Ecol. 2016, 58, 567-576. [CrossRef]

41. Avery, M.I. Winter Activity of Pipistrelle Bats. J. Anim. Ecol. 1985, 54, 721-738. [CrossRef]

42. Heyerdahl, E.; Brubaker, L.; Agee, J. Spatial controls of historical fire regimes: A multiscale example from the interior west, USA. Ecology 2001, 82, 660-678. [CrossRef]

43. Dillon, G.K.; Holden, Z.A.; Morgan, P.; Crimmins, M.A.; Heyerdahl, E.K.; Luce, C.H. Both topography and climate affected forest and woodland burn severity in two regions of the western US, 1984 to 2006. Ecosphere 2011, 2, 1-33. [CrossRef]

44. Perry, R.W.; McDaniel, V.L. Temperatures below leaf litter during winter prescribed burns: Implications for litter-roosting bats. Int. J. Wildland Fire 2015, 24, 544-549. [CrossRef] 